Portland State University

PDXScholar

$5-24-2018$

\title{
The Path to Modern Iran: an Examination of Shiite Islam's Influence (1900-Present)
}

Autymn A. Langford

Portland State University

Follow this and additional works at: https://pdxscholar.library.pdx.edu/honorstheses

Let us know how access to this document benefits you.

\section{Recommended Citation}

Langford, Autymn A., "The Path to Modern Iran: an Examination of Shiite Islam's Influence (1900-Present)" (2018). University Honors Theses. Paper 590.

https://doi.org/10.15760/honors.599

This Thesis is brought to you for free and open access. It has been accepted for inclusion in University Honors Theses by an authorized administrator of PDXScholar. Please contact us if we can make this document more accessible: pdxscholar@pdx.edu. 
The Path to Modern Iran:

An Examination of Shiite Islam's Influence (1900-Present)

By:

Autymn Langford

An undergraduate thesis in partial fulfillment of the requirements for the degree of

Bachelor of Arts

in

Political Science

\&

Political Science Honors \& University Urban Honors College Programs

Thesis Advisor:

Dr. Lindsey J. Benstead, Ph.D.

Portland State University

2018 


\section{Table of Contents:}

Abstract

Introduction

Overview of Shiite Islam

Religion \& Politics in Iran Pre-1900

The Constitutional Revolution (1905-1921)

Reza Shah Pahlavi (1925-1941)

Mohammad Reza Shah Pahlavi (1941-1979)

The Appeal of Mohammad Mosaddeq

The 1953 Coupe \& Return of the Pahlavi Shah

The Emergence of Ayatollah Khomeini

The 1979 Revolution

The Islamic Republic of Iran (1980-1999)

Middle Ground Politics in Iran (2000-Present)

Concluding Remarks 


\begin{abstract}
:
Throughout history, we have struggled to determine how best to govern and maintain our societies. Many times religion has found a place in government by providing an enforceable framework of expected behaviors and laws to impose over citizens to create order in society. In a county that separates church and state, the government attempts to not enact laws that are directly derived from any one religious ideology to avoid imposing religious codes onto citizens who choose to not abide by that particular religious code. In Iran the government has taken form as a theocracy, referred to as the Islamic Republic of Iran, and the state is ruled by Islamic laws handed down by the country's Shiite leadership.

The purpose of the essay is to examine the influence of Sharia (Shiite) Islam in Iranian politics with an emphasis on the importance of 20th Century regimes. The consideration of Shiite traditions in Iran politics resulted in the formation of either an adverisionist state or an conformist state. In an adverisionist state, political leaders consciously create policies and take actions to repress traditional Shiite practices and curb the influence of Islam in Iran. Oppositely in an conformist state, political leaders derive policies from Shiite Islamic traditions. During the 20th century, Iran experienced periods of drastic change, ultimately culminating to the 1979 Revolution which would lead to the establishment of the theocratic, conformist Islamic Republic of Iran and officially establishing Shiite Islam as a central element of the Iranian national identity.
\end{abstract}




\section{Introduction:}

Throughout the course of history, religion has played an undeniable role in the political structure of Iran, whether or be through deliberate inclusion or exclusion of religious policy. This has allowed religion to remain at the forefront of the Iranian political mind, as the historical significance of Islam's role in Iranian politics facilitated the integration of Shiism into the Iranian national identity. The social, political, and economic environment of contemporary Iran is inexplicably linked to Shiite Islam's influence on regimes throughout Iranian history, particularly in the 20th Century.

When examining the modern state of Iran, it is impossible to objectively evaluate politics without considering the role of religion. Consideration of religion throughout Iran's history has been constant, either through direct aversion or direct adherence to Shiite Islamic principles. By examining the interaction between 20th Century Iranian political regimes and religion, the important influence of religion in Iranian politics can be easily traced up to the present.

In order to demonstrate the development of the Shiite Islam as a continuously influential political force in Iran, this paper will examine: the origins of Shiite Islam in Iran, religion and politics in pre-1900 Iran, the Iranian Constitutional Revolution (1905-1921), the reign of Reza Shah Pahlavi (1925-1941), the reign of Mohammad Reza Shah Pahlavi (1941-1979), events leading up to the 1979 Revolution, the political environment of Iran following the revolution, and the shape of modern Iran. By process of these examinations, I aim to solidify the connection between the historical significance of Islam in Iran and the interconnection of Shiite Islam as a central part of the Iranian national identity, eventually influencing the formation of a conformist government, the Islamic Republic of Iran. 


\section{Overview of Shiite Islam}

Shiism is, "an integral part of the Iranian religious and cultural landscape"which served as the dominant branch of Islam in Iran from the establishment of the Safavid dynasty until the 1920 's, but would later experience a great resurgence of political importance (Hashemi-Najafabadi 1). The implementation of Shiite Islam is largely based around the theory of Imamate as the absolute religious and political leadership of the Muslim community. The theory of the Imamate stems from Twelver Shi'ism, which follows the belief in twelve, "divinely-guided, infallible leaders" as the true successors of the Prophet Muhammad.

Shiite Islam is built around several central beliefs, such as:

Islam as a total way of life even during the Occultation of the Imam, paying great attention to Islamic social and political philosophy and jurisprudence, insisting on the necessity of establishing a religious government in the absence of the Imam, believing in the unity of the state and religion during the Occultation period, and emphasizing on the responsibility of Muslims to take preliminary steps toward the promised global just government of the Imam Mahdi. (Hashemi-Najafabadi 193-194)

During the presence of the Imams, (632-874), the government operated under a strict Islamic leadership. After the Battle of Karbala, which resulted in the death of Imam Husayn ibn Ali and many of his supporters, the remaining Imams began a traditional of lessened political activism. This signified the beginning of the Great Occultation, a period marked by the disappearance of the Twelfth Imam Mahdi, and continues to up to present day (Keddie 7). This inspired the belief that in the absence of the Imam, is it the responsibility of loyal Muslims to 
establish an Islamic state, a belief that would perpetuate the consideration of Shiite Islam in later political regimes.

\section{Religion \& Politics in Pre-1900 Iran}

In the centuries before Iran's most identifiable leaders came to power or the advent of Islam, Iran was ruled as the first Persian empire under the Achaemenid dynasty (BBC Iran Profile). This formidable empire was ambitious, building the grand city of Persepolis and attempting to conquer the Greeks (BBC Iran Profile). In approximately 330, the Persian Empire fell to the Greeks, who were led by Alexander the Great, and became part of the Greek Empire under the Arsacid dynasty (BBC Iran Profile). During this time, Zoroastrianism was the dominant religion practiced by ethnic Persians residing in what is now Iran (BBC Iran Profile). Zoroastrian church leaders held important roles, serving as "moral supporters of the kings and their policies"(Kheirabadi 6). Following the Muslim conquest of Persia in 651, the Sasanian Empire came to an end and Zoroastrians became heavily persecuted. While the practice of Zoroastrianism did not disappear, it was widely discouraged and hidden as many grew to adopt Islam. After the establishment of Islamic rule in the 7th century, "Persian (Iranian) intellectuals played a major role in developing the Islamic civilization. They contributed to the development of many branches of Islamic learning such as theology, philosophy, literature, jurisprudence, medicine, science, history, and geography" (Kheirabadi 6). Islamic religious advisors became influential aids to Muslim kings as each Islamic dynasty would be aided members of the Islamic Caliphate. Members of the Caliphate advocated for further Arab conquest in the region, promotion of Islamic principles, and helped to enforce the Islamization of Persia. 
Yet religious dominance did not always coincide with political dominance, from the 9th century until the 13th century the political influence of Islamic Caliphate declined and was replaced with a series of independent Turkish dynasties. In the early 12th century, Genghis Khan captured the country establishing a Mongol dynasty in Persia (BBC Iran Profile). Until the 15th century competing Iranian, Turkic and Mongol dynasties attempted to gain full power over Iran and its surrounding territories, making it harder for the Caliphate to ally with any one regime (BBC Iran Profile). Eventually a traditional Islamic ruler regained power in 1501, Shah Ismail I of the Safavid dynasty, who declared Shiite Islam the state religion and reinstated the importance of the Caliphate (BBC Iran Profile). During the Safavid dynasty (1501-1736), a dynasty which is widely considered to be the beginning to modern Iranian history, Safavid leaders "managed their government as a semi-theocracy... kings considered themselves spiritual rulers as well as political" but are remembered primarily for, "the emergence of a unified national consciousness"(Kheirabadi 6).

The Safavid had strong relationships with wealthy merchants and members of the religious leaders that composed the ulama, the regime was successful in re-establishing Persia as an economic force in the region, employed a system of checks and balances alongside their religious government, and supported development of the agriculture field. In the later years of the otherwise strong regime, the Safavid struggled to maintain their military leverage over surrounding tribes and eventually would lose their power to a series of short lived regimes before the establishment of the Zand dynasty (1751-1794). The Zand state was militarily weak, losing crucial Safavid land gains to the Ottomans, however Zand rulers managed to maintain relative 
peace, steady economic growth, and made attempts to appeal to their subjects and not operate as absolute monarchs like the Safavid.

In 1794, Mohammad Khan Qajar was instrumental in deposing the last Zand Shah, and established the Qajar dynasty (BBC Iran Profile). The Qajar dynasty started the Westernized modernization of Iran, and was commonly meet with scorn due to their embarrassing loss of territory to Russia and concession of economic power to Great Britain. Additionally, the Qajars "referred to themselves as the shadow of God on earth" and maintained absolute power by building up a strong support network of Shiite religious leaders used to "further legitimize their rule over their subjects" (Kheirabadi 6).

In the 1890's, due to a series of territory losses, Nasir al-Din Shah made a series of trade concessions to European powers. These concessions only served to worsen the economic welfare of the state and contributed to the widely held belief that the Qajars did not care about their subjects, and the Qajars relied greatly on the Russians and the British to maintain their rule. However, conflict between Nasir al-Din Shah and the public came of a head in 1890 when the Shah granted a tobacco concession that gave a Britain army major a "full monopoly over the production, sale, and export of tobacco for fifty years" (Kiddie 61). This concession was extremely detrimental to Iranian tobacco farmers and workers by endangering job security and undercutting their profits, but enraged all Iranians who wanted foreign power kept out of Iranian political affairs.

In 1891 protests against the tobacco concession began in major Iranian cities. At first, it was primarily bazaaris, merchants, workers and farmers directly involved in the tobacco industry that protested the concession, however the ulama also got involved in the tobacco protests. While 
the latter were motivated to protect their livelihood, the ulama was concerned with protecting Iranian interests from foreign domination due to their belief that such concessions were dangerous under the control of non-Muslim foreigners, as the ulama was concerned that Islamic tradition under foreign power would deteriorate (Kiddie 61). The ulama lead protests beginning in Tabriz that eventually spread to Mashhad, Isfahan, Tehran, and beyond (Kiddie 61). In late 1891, the protests came to a head in the form of a successful nationwide tobacco boycott that lead to a suspension of the concession's operation in some cities (Kiddie 61). Unfortunately, at a protest in Tehran the government opened fire on a unarmed crowd, sparking further protest and by 1892 the concession was suspended indefinitely by the Shah's government. The consequence of canceling the concession left Iran with a large debt to the British Imperial Bank, however one positive effect of the tobacco protest was that it was, "the first successful mass protest in modern Iran, combining the ulama, modernists, merchants, and ordinary townspeople in a coordinated move against government policy"(Kiddie 62). This marriage between the power of the bazaaris, the ulama, modernists, and secularists reformers would continue to be important as Iran entered a new century (Kiddie 62).

\section{The Constitutional Revolution (1905-1921)}

As the 20th century approached, Iranians began to voice opposition against the Qajars concerning their "arbitrary" royal power, corruption, extravagance, and tendency to let foreign powers interfere in Iran's state affairs (BBC Iran Profile). Advocates of the revolution were primarily wealthy merchants, the religious ulama, disenfranchised Iranian citizens, and radical reformers from various schools of thought (BBC Iran Profile). The "economic and political dislocations" that the Iranian people endured as a result of Western encroachment had great 
influence on kindling the Constitutional Revolution (Kiddie 58). Iranian merchants and works struggled to compete with cheap European exports or afford to purchase pricey European imports, as Iranians struggle to establish operational factories and the international value of silver, the standard of Iranian currency dropped. This resulted in, "growing economic discontents and resentment against European rivals" (Keddie 58). While some groups enjoyed moderate benefits of trade with European powers, many merchants and laborers who traveled outside Iran "could witness reforms and hear liberal or radical ideas suggesting ways that governments could change and could undertake self-strengthening policies of a kind that might better Iran's condition and free it from foreign control"(Keddie 58). In addition, the ulama reasserted their resistance against "the alarming trend" of Iran's trade activities with European nations, transactions in which it seemed Iran always lost more than was to be gained (Keddie 59).

In 1905, opposition against the Qajar regime demanded political reform. Two central demands of revolutionaries concerned the formation of a representative adalatkhaneh or House of Justice and also the disposal of Ain ad-Dauleh, who was responsible for racking up many foreign debts (Kiddie 66). Some more advanced constitutionality revolutionaries also advocated for the formation of a representative assembly, Majles and a formal Constitution.

In 1906, Mozaffar ad-Din Shah Qajar was forced to issue a decree which outlined the drafting of an Iranian Constitution, limitations on royal power and foreign influence, and the establishment of a parliament called the Majles. The function of the constitution was to:

Set up a true constitutional monarchy in which the Majles approval was required on all important matters, including foreign loans and treaties, and in which ministers would be responsible to the Majles. Equality before the law and 
personal rights and freedoms, subject to few limits, were also granted. (Keddie

However, the decree was difficult for the aling monarch Mozaffar ad-Din Shah Qajar to enforce. After Mozaffar ad-Din Shah Qajar's death in 1906, his son and successor the "cruel and autocratic" Mohammad Ali Shah worked to destroy the policies that his father had vowed to protect, stoking the fires of revolution once again by repressing the operation of the Majles with the military power of the Russians and the British and ignoring the fundamental rights laid out in the Constitution as well as limitations on royal power (Kiddie 69). The constitution did not outline what body was responsible for selecting the Prime Minister, so one the first things Mohammad Ali Shah did to undermine the legitimacy of the Majles was make Mirza Ali Asghar Khan, known as the Atabak who was a previously dismissed government official, the new Prime Minister (Kiddie 69). The Shah believed that Atabak would be instrumental in the dismantling of the Majles, however Atabak instead attempted to negotiate a compromise between members of the Majles and the Shah (Kiddie 70). Eventually, in 1907 Atabak was assassinated and the Shah had to find another way to usurp the Majles. This lead to the Anglo-Russian Entente in August 1907, which resulted in a treaty that divided Iran into three distinct spheres, attributing northern and central Iran to the Russian sphere, southeast Iran to the British sphere, and the area in between was declared a neutral zone (Kiddie 70). The Iranian people were never consulted concerning this decision and the Majles was not included in the ratification of this treaty.

Foreign interference in the country did not stop despite protest from Iranians, instead the British and Russians increased their presence by supporting the remaining Qajars and helping to suppress uprisings. In June 1908, Mohammad Ali Shah was successful in suppressing the role of 
the first Majles using a coup backed by the force of the Cossack Brigade (Kiddie 70). This event subsequently lead to the arrest and execution of several popular nationalist leaders (Kiddie 70).

In 1909, pro-Constitution forces marched on the Iranian capital of Tehran, captured the city, disposed Mohammad Ali Shah, reinstated the Constitution, and Ahmad Shah Qajar assumed the role vacated by his father as he fled to Russia. Ahmad Shah was tasked with repairing the damage done by his father, which would be crucial in order to restore the citizen's trust in their leaders and avoid another further uprisings. To do this, the Majles needed to be able to function as it was intended to, foreign powers needed to be kept out, and royal power needed to remain in check. Initially, it seemed that changed was possible under the rule of Ahmad Shah, but soon it would become clear that the young, inexperienced ruler could not give the Iranian people what they needed. The Majles failed to make any significant progress from 1909-1920 as the nation lacked a strong central government to ratify policy and the Majles as an institution lacked the power to enforce change. To make matters worse, Iran was heavily impacted during World War I. While Iran was officially neutral, its geographical location turned much of the county into a battlefield and did severe damage to agriculture industry and rural areas, further seeding discontent in the hearts of Iranians that wanted foreign influence kept out.

By 1920, Ahmad Shah had effectively lost control of everything outside of the capital city of Tehran and the progression of the country was completely immobilized due to conflicting internal political interests and increasing dependence on foreign powers. The weak state of the economy led the Shah to obtain loans for the National Bank of Persia and enter into the Anglo-Persian Agreement of 1919 (Keddie 54). Under this "agreement", which was never ratified by the Majles, the British enjoyed the vast majority of the oil drilling rights and profits of 
the Anglo-Persian Oil Company. In exchange the British provided army equipment, a sterling loan worth 2 million, lower customs tariff, and a promise to build a railroad system (Keddie 55). Yet by 1921, Ahmad Shah's time to repair the country had run out. In February of 1921, an efficient coupe was executed by former Minister of War Colonel Reza Khan. Soon after, Reza Khan became Prime Minister and repealed the Anglo-Persian Agreement, which was deeply unpopular among the public. Reza Khan spent the remainder of 1921 until 1923 suppressing revolts against his leadership and attempting to push the Russian army out of Iran with help from the British (Keddie 55).

\section{Reza Shah Pahlavi (1925-1941)}

In 1925, Ahmad Shah was officially deposed despite the fact that he had been living outside Iran withdrawn from politics since the coupe in 1921. This marked the official end of the Qajar dynasty and the beginning of the Pahlavi Dynasty as Reza Khan became the new Shah. He took the name "Pahlavi", a distinctly Persian name of non-Islamic origin. Under the direction of Reza Shah, a constitutional monarchy was established despite a strong national desire for a Republican based system (Kheirabadi 7).

As Reza Shah begun to exercise his newfound power, "a number of major changes in Iran's economy and society, despite a formal retention of the constitution and the Majles elections, decision making was increasingly monopolized by the Shah" as "the Majles became a rubber stamp and the constitution was paid lip service only"(Kiddie 88). In 1931, the Shah passed a law outlawing Communist and Socialist propaganda, creating effective censorship laws created an environment in which "only official nationalism stressing national homogeneity, anticlericalism, modernity, and strength" derived from the pre-Islamic history of Iran could 
"flourish" (Kiddie 88-89). This marks a critical point in the development of the Shah's government as an adversist regime, working to systematically remove old vestiges of Shiite Islam from the Iranian political structure.

Reza Shah agreed to involve five Islamic clerics that would "be involved in government decision making to ensure that the government functioned within the Islamic context"(Kheirabadi 7). This agreement was quickly abandoned in order to give way to modernity as Reza Shah “considered Islamic traditions an impediment” to Iran's potential for advancement (Kheirabadi 7). This lead to religion being replaced with secularism in hopes of quick Western modernization. Reza Shah was successful in "secularizing the Iranian legal system, education, and bureaucracy" and limiting the influence of the Islamic clergy (Khetibadi 7). Reza Shah focused on the creation a strong Iranian army, unity between ethnic groups, expansion of education, establishment a railroad network, and the development of the University of Tehran (Kheirabadi 7). Yet in pursuit of modernity Reza Shah also took some unforeseen missteps that did not help him curry the favor of the Iranian people.

Between 1925 and 1930, Reza Shah laid the groundwork for a series of overhaul reforms, all on which were incorporate in favor of Western modernity and not Islamic tradition (Kiddie 89). High taxes were imposed on tea and sugar to pay for a national railroad, a new uniform land tax was established, and a large portion of government spending shifted to the strength of the Iranian military, which Reza Shah would routinely use in to order to exert control (Kiddie 89). As the government became more centralized, Tehran experienced a surge of urbanization and the streets were abuzz with ideas, many of which could not be freely spoken of due to government censorship (Kiddie 89). Additionally, a series of legal reforms were handed down, some of 
which reduced the influence of the Islamic clerics in the judicial branches of government in favor of a "modern, non-clerical judiciary and a uniform, centrally controlled legal system". Under Reza Shah, "the state took numerous measures to weaken the clergy,taking away most of their role in lawand education", thus further decreasing the touch of Islamic values in government and the day to day lives of Iranian citizens (Kiddie 89-103).

While these changes were considered positive by the Shah's supporters, they were put into effect alongside a strong oppression toward traditional Islamic practice. In pursuit of a rapidly modernized Iran, Reza Shah was cruel to traditional Muslims which would only breed issues for his regime. While previous monarchs relied heavily on legitimacy handed down by the support of the ulama, Reza Shah turned away turned away from this tradition and worked to keep Islamic influence far away from issues of the state. Despite the existence of the Majles, Reza Shah functioned with a dictatorial level of automatomy, often stating that "every country has its own ruling system and ours is a one man system"(Keddie 60).

In the 1930's, Reza Shah would have to compromise his ambitious goals for Iran's economy with the occurrence of the Great Depression. The depression would cause demand for Iran's trade wares to drop, and thus the need arose to suppress a series of rural uprisings as discontent grew (Kiddie 92). In order to cope with this issue, the state embarked on a program of self centric economic development, primary tied up in urban expansion projects and the aversion of foreign loans by means of "large increases to indirect taxes" (Kidde 95). By 1940, 58.5 percent of all domestic capital investment was tied up in urban expansion projects in the capital city of Tehran (Kiddie 95). In the latter half of the 1930's leading into the new decade, half of Iran's government's income was wrapped up in the modernist development projects, while the 
agrarian sections of the country continued to struggle and receive little to no aid or encouragement (Kiddie 95). There was little agrarian reform, and the policy that was past only benefited wealthy landowners, contributing to the disregard for the condition of the lower classes and hindering the full economic transformation that Reza Shah desired. Instead of working to find solutions that would benefits all Iranians, Reza Shah "continued a policy if military control without economic solutions" which would serve as "the weakest point" of his modernization program (Kiddie 95).

Reza Shah's focus on Western secularization, the military, and education primarily created opportunities for the urban upper classes, while the rest of Iran did not experience the positive side of the Shah's policies. Overtime, this issue would create " two cultures" in Iran, one which "became increasingly Westernized and scarcely understood the traditional or religious culture of most of their compatriots" and another which continued to follow the ulama and the traditional teachings of Shiite Islam. Eventually, resistance to his regime would cause Reza Shah would abdicate and transfer power to his son Mohammad Reza, and the second Pahlavi Shah would rule for short period of time before he too experienced the backlash of the Iranian people.

\section{Mohammad Reza Shah Pahlavi (1941-1979)}

Under Mohammad Reza, the country undertook a series of Western-like, socioeconomic policies that transformed the country (Kiddie 148). While Iran started to develop what seemed to be "impressive industrial, agricultural, and infrastructure projects and a number of social welfare activities", many were not convinced of the legitimacy or intentions of the Shah, believing that above all else the Pahlavi regime was concerned with pacifying Iran's political elites and Western actors (Kiddie 149). In the 1960's Mohammad Reza launch a new series of reforms, 
characterized as the White Revolution, that was aimed at land reform, public ownership of industries, nationalization of the forest, voting rights for women, profit sharing programs, and further education for rural sections of the country (Kheirabadi 11).

\section{The Appeal of Mohammad Mosaddeq}

Due to mounting pressure and dissatisfaction brought on by high unemployment and high inflation caused by a British boycott of Iranian oil, Mohammad Reza left Iran (Kheirabadi 9). During the Shahs absence, Mohammad Mosaddeq became the leader of a democratic Iran. Mosaddeq was championed by the Iranian people because of his shape resistance to foreign interference and the nationalization of the Iranian oil industry (Kheirabadi 9). The Iranian people were generally optimistic about the rule of Mosaddeq and it seemed that the nation was finally going to get a crack at the democratic system many wanted. But it was not met to be. In order to protect British and American oil interests in the region, the United States and Britain staged a coup to remove Mosadde and restore Mohammad Reza. The coupe was successful, returning the Western thinking Shah to power. Once again Islam would take a backseat to the ambitions of a Pahlavi Shah.

\section{The 1953 Coupe \& Return of the Pahlavi Shah}

From the outside, Iran seemed to be changing for the better under the Shah's rule. Yet, from the perspective of many proud Iranians, the Shah had sold them out for the gain of Iran's most wealthy. Religion played little role in the Pahlavi state, the emphasis was instead shifted to secularism, with a focus on modern relations with the West and restoration of cultural elements of Persia before Islamic dominance (Malani 3). Under Mohammad Reza, "rapid removal of social taboos and restrictions that had enslaved women for centuries" begin to weaken Islamic 
elites. Mohammad Reza Shah Pahlavi later implemented more secular women's rights, such as the right to vote, the right to hold important political offices, preside as judges, and pursue higher education (Farzaneh 216). Mohammad Reza also advocated for the Family Protection Law and encouraged women to embrace Western culture. The corruption of the government did not allow for many of the policies implemented under the White Revolution to be fully actualized.

But these mishaps did not go unnoticed by the Iranian people or anti-Shah religious leaders. As Abbas Milani writes in his article Zoroaster and the Ayatollahs, "the leftist, centrist, and clerical opposition to the Shah "over determined" the politics to the detriment of the cultural freedoms" (Milani 6). Mohammad Reza ruled like a totalitarian dictator with legitimacy handed to him personally by two of the world's most influential powers. He attempted to continue the modernization of Iran that his father had started as external pressure for more change grew. Mohamad Reza continued to ignore the religious past of Iran and focused on secularist policy. The Shah underestimated the power and dissatisfied of his people, which would lead to this downfall.

\section{The Emergence of Khomeini}

The failure of the Constitutional Revolution and the resurfacing of political activism for the fundamentalist cause (Hashemi-Najafabadi 205). Ayatollah Khomeini was an Islamic fundamentalist that begin to speak out against the rule of the Pahlavi Shahs(Kheirabadi 12). Khomeini was especially upset by many of the programs that were launched during Mohammad Reza's White Revolution and various other policies which were viewed as an offense to Islam. Speaking out against the Shah was not permitted, but Khomeini persisted and was eventually exiled (Kheirabadi 12). Khomeini published many works about how the state of Iran should be 
run, which allowed him to gain many followers.

Khomeini and other fundamentalists thought that "the only way to revive Islam was to reassert the political role and function of the Imamate in the absence of the Imam"(Hashemi-Najafabadi 205). Khomeini defended a conservative, fundamentalist reading of Islam as well as the function of important Islamic figures like the ulama. One concept that become inexplicably attached to Khomeini is Wilayat-e-faqih, which was based off Khomeini's belief in a, "complete subordination to the political institutions of Islam" and, "governance of the faqih as the real wielders of legislative, executive, and judicial power" in addition to the, "duties incumbent upon every Muslim in establishing an Islamic government" (Hashemi-Najafabadi 206). The persuasive power of Khomeini as a revolutionary figure would become an issue of the Shah and the newly Westernized Iran.

\section{The 1979 Revolution}

The main goals of the 1979 Iranian Revolution focused on freedom from western influence, a desire for democratic government, and promotion of nationalist and leftist values (Milani 2). While many Iranians were unclear about exactly what they wanted as a result of the revolution, they had a better idea of what they did not want, as "they did not want a government that would promote the Western way of life at the expense of Iranian and Islamic values. They wanted a government that was democratic and that respected human rights" (Kheirabadi 1).

In 1979, Ayatollah Khomeini returned after 14 years of exile. In order to build up a coalition, Khomeini appealed to many different groups, often promising various things to different groups of people. To those who wanted to help unemployment, Khomeini promised economic change and to women, he promised equal rights. Upon his return, Khomeini and his 
followers turned their attention to Shahpur Bakhtiar, the Shah appointed Prime Minister of Iran (Kheirabadi 2). Khomeini formed his own government of which he appointed the religious Mehdi Bazargan as acting Prime Minister, putting Bakhtiar in a position of having to prove his legitimacy to those who favored Khomeini. Bakhtiar was unsuccessful, so when the Iranian armed forces withdrew their blind support for Bakhtiar in exchange for neutrality, Bakhtiar was forced to pass power to Khomeini (Kheirabadi 2). Khomeini and his followers then crafted a referendum that would legitimize the Islamic Republic, thus ousting Mohammad Reza. The Islamic Republic of Iran's constitution closely mirrors that of the French presidential-parliamentary system, with the very important inclusion of a provision that gives the supreme religious leader of Iran the greatest political and religious authority (Kheirabadi 2). Khomeini and his interpretation of Shiite Islam became the law of the Iranian land.

Considering the richly complex history of Iran, the answer to this question depends largely on what point of view one chooses to analyze this issue from. It is frequently argued that the Iranian Revolution evolved largely from ideological desires on the part of Islamic conservatives that wanted to rid Iran of Western influence which was heavily encouraged by the Pahlavi Shahs. However, to believe that an event as impactful as the Iranian Revolution stemmed purely from an ideological war of religious values is to ignore the many important factors that have shaped Iran into what it is today. In order to fully understand how the Pahlavi dynasty fell from power and paved the way to the establishment of the Islamic Republic of Iran, it is necessary to evaluate relevant cultural, social and economic factors that created the perfect environment for the overthrow of the Pahlavi regime.

Religion played little role in the Pahlavi secular state. Emphasis was instead advanced to 
secularism, modern relations with the West and focusing on the cultural elements of Iran and Persia before Islamic dominance (Malani 3). Under the rule of the Pahlavi's, one of the greatest issues facing the regime was "[accentuating] the pre-Islamic component of the country's heritage and [diluting] the Islamic element"(Milani 3). This lead the regime to support projects focused on restoring classic Persian cultural tradition and bringing those traditions back into the forefront of the Iranian mindset (Milani 3). From this revival came elaborate celebrations and art festivals that did little to pay homage to Islamic influence on Persian tradition (Milani 3). Perhaps the most significant of these festivals was the series set to celebrate the 2,500 Years of the Persian empire, dedicated to Persepolis, the old capital. The intention of these festivals was to pay homage to Iran's Persian history and celebrate the current achievements of the country. However, the festivals were not open to the general public and became yet another source of controversy for the Pahlavi regime.

Policy changes that impacted the urbanization and the agricultural sector also came to Iran under Pahlavi rule. While the Shah did want to boost up the agricultural industry, he also wanted to increase trade relations between the West and Iran, promoting Western business expansion in the region (Kiddie 150-155). These changes in policy did little to help the farming dependent, lower class members of Iranian society, but they did a lot to strengthen the Shah's relationships with political elites and foreign business interests. While a small number of peasants benefiting from agricultural reform, generally the policies were not executed well enough to result in widespread success (Kiddie 152). In reviewing this history, it is important to note how these political occurrences pushed Iran toward the 1979 revolution.

However, the Shah failed to realize that Iranian society would not tolerate the 
authoritarian rule even of the most modernizing monarch who is "capable of delivering impressive economic development" once they come to realize that the "gifts" they had been given are really just basic rights, except Iranians only get them when they do not voice any opposition to a repressive regime (Milani 6). Despite economic and social modernity, there was no democracy, which seeded social and cultural discontent. Concerning the Shah's festivals, some Muslim conservatives interpreted the reorientation towards focusing on Persian history minus Islam as a direct attack on traditional Islamic values (Milani 6). Later some extremist went as far as pushing to destroy the site at Persepolis and banishing the existence of the site to a state of Jahiliyyah (Milani 5) Lastly, reforms to the agricultural and industrial industry did not have an overwhelming positive impact on the lower class of society, creating a larger, more upset lower class. Given a more in-depth look at how these events affected the feelings of many Iranians towards the socio economic issues of their country under the Shah's rule, it is not impossible to see how many began to follow the path to revolution.

On the other side of the Shah, with a view that differed from Iranian Marxists, or the ulama, or Iranian students was Ayatollah Khomeini and his followers. The overarching goals of the 1979 Iranian Revolution concerned championing freedom from western influence, desire of democratic government, and promotion of nationalist and leftist values (Milani 2). But what did the Iranian people get? Khomeini, who wanted to create a theocratic state with culturally anti-modern values. After coming to power, Khomeini publicly claimed that the revolution's purpose was not to serve as a instrument for economic change, but rather to bring about a religious state based off Islamic ideals. Khomeini condemned Western values and any mark of modernity in Iran (Milani 3). Under Khomeini, it was top priority to "reverse the pre-Islamic 
ardor of the Pahlavi era ... to dilute, diminish and at times altogether erase from the cultural memory evidence of Iran's non-Islamic past” (Milani 3).

But it must be understood that not only did Khomeini state that he would never seek a role in the government after the overthrow of the Shah's regime, but he also never disclosed his true ideological intentions to the whole of his supporters:

The only concern that Khomeini added to the nationalist demands was the government's violation of Islamic principles. He steadfastly maintained that an Islamic government would guarantee national independence and provide political freedom for all Iranians. In the final weeks of the revolutionary conflicts, Khomeini repeatedly declared that independence and freedom would be the essence of any Islamic republic. (Parsa 2)

Given this, it would be difficult to argue that the Iranian Revolution was purely motivated by a desire to establish to Islamic state. While many Iranians had issues with the Shah's government, not everyone fought for freedom on religious grounds nor did they want to establish a wholly religious state, "while it is true that segments of Iranian intellectuals and students fought for an Islamic government, the majority of them did not fight for a theocracy...the majority of individuals who participated in the struggles did not volunteer to give their lives, but instead expected to improve their lives" (Parsa 1).

While religion played a relatively equal role in driving the 1979 Iranian Revolution, it became more important later during the establishment of Khomeini's rule and the continuation of the Islamic state today. Seeing as how so much of the modern Iranians life is influenced by religion, it is not difficult to see why many argue that religion was the main cause of the Iranian 
Revolution. In reality, there was a relatively equal balance of responsibility to be shared across discontent that stemmed from various cultural, social and economic issues that allowed the Islamic State of Iran to take control in the aftermath of the 1979 revolution.

\section{The Islamic Republic of Iran 1980-1999}

In the years following the 1979 Revolution, a fully Islamic state headed by Supreme Leader Khomeini was implemented. All facets of the politic and legal system are derived from Islam. The laws of the country impact the everyday lives of Iran's to varying degrees. Education in Iran has continued to be more widespread since the establishment of the Islamic state. Rural areas receive more education, literacy rates across the country have improved and all citizens, including women, have access to free higher education.Gender inequality in Iran and human rights violations commonly associated with the Islamic Republic of Iran in recent years stems from the government's desire to use Islamic principles to justify the perpetuation of a male-dominated society. Since the establishment of the Islamic state in the aftermath of the 1979 Revolution, the plait of Iranian women has only deteriorated. When examining how the 1979 Revolution shaped the modern Iranian woman's role in politics, economy, media, and family; it becomes clear that men and women do not enjoy the same human rights as gender relations in modern Iran are based on a conservative interpretation of Islam used to justify a prevailing tradition of male dominance.

Since the establishment of Islam as the ruling doctrine of Iran during seventh century, women have had, "little power over their sexual, psychological and emotional lives" (Farzaneh 206). During the early years of Islamic influence, employment opportunities for women were limited by strict gender segregation and women we viewed as an objects that existed largely to 
service male sexual desires (Farzaneh 207). As Quranic rules were implemented, male dominance was promoted and women were viewed as being lower than men (Farzaneh 207).

During the Qajar Dynasty, the Constitutional Revolution inspired Iranian women to challenge female oppression for the first time in centuries. Women took part in political protests, fighting for the right to vote, forming women's organizations and launching a direct attack against patriarchal Islamic rules (Farzaneh 208). Prior to the Constitutional Revolution, the rights of the Iranian women closely mirrored their status today; they could only could leave the house with the permission of a male family member wearing the chador, they were not permitted in some public spaces and there were widely "regarded as mindless" in accordance with Islamic principle (Farzaneh 209). Despite their best efforts, even after the Constitutional Revolution women, "still counted as criminals and retarded individuals" as many contended that, "God did not give women the ability to vote" because, "women's brains lack the capacity to deal with serious matters" (Farzaneh 209). During World War I, Iranian women wanted to take part in the war effort as other women did in Western countries, but they were rebuffed and confined to traditional duties (Farzaneh 209).

During the Pahlavi Dynasty, under the reign of Reza Shah Pahlavi, "rapid removal of social taboos and restrictions that had enslaved women for centuries" begin to weaken Islamic elites. Mohammad Reza Shah Pahlavi later implemented more secular women's rights, such as the right to vote, the right to hold important political offices, preside as judges, and pursue higher education (Farzaneh 216). Another important example of pro-women legislation from the Pahlavi era is the Family Protection Law, which raised the legal marriage age for women, gave women more pathways to pursue divorce, gave women greater chance at gaining child custody, 
and made it so a man could only have two wives with the express permission of the court or his first wife (Farzaneh 216). Mohammad Reza Shah's regime encouraged women to embrace Western culture, there was less pressure to many young and have many children, the motto Iranians took to concerning family planning was, "two children is enough" (Mohammad et al 2014). This new license to modern womanhood under the Shah, while not perfectly equal, still signified a huge step forward toward modernity and equality for the average Iranian woman.

However, after the 1979 Revolution, many women found that "the long history of patriarchal Islamic traditions returned with a vengeance" (Farzaneh 216). Women were instrumental in the success of the 1979 Revolution by taking part in demonstrations and Ayatollah Khomeini promised women new rights if the revolution was successful (Farzaneh 217). Khomeini believed that women's participation in politics should be used in favor of Islam and the ideal Muslim woman would be one that could, "accomplish all her traditional duties and also be aware of her social responsibility" to Islam (Farzaneh 218). Almost immediately after the Islamic state was established, the Family Protection Law was repealed because it interfered with men's rights and was thus against Islam. The repeal of this policy lowered the legal marriage age for females to 9 (later changed to 13), and took away nearly every legal pathway a woman had to initiate divorce, maintain custodial rights, or receive alimony. Additionally, "the Islamization of state and society established both sex segregation and the mandatory hijab" which helped to enforce a "culture of chastity"(Farzaneh 220). According to Delaram Farzaneh, author of "One Step Forward, Two Steps Back" :

Compulsory hijab is one of the most instructive discriminations against women's fundamental human rights in Iran...[it] not only discriminates against women, but 
also explicitly violates women's right to freedom of expression, thoughts, speech, and conscience...[an] imposition that reaffirms gender inequality and suppression. (222)

The requirement that all women wear hijab in public spaces or be subject to punishment, restricts women's rights to expressionism which violates Articles 3 and 26 of the ICCPR and Article 19 of the Universal Declaration of Human Rights (Farzaneh 222). Limitations on education for women also reinforces inequality. At the university level, women are only allowed to study certain subjects and there are quotas on the number of women that can study hard sciences and mathematics. The Iranian Parliament has stated that these limitations stem from the belief that, "some fields are not suitable for women's nature" and gender-segregated classes necessary "for balance" (Farzaneh 234).

Women's rights are outlined in two articles of the Iranian Constitution, Articles 20 and 21. Article 21 clearly and strictly limits women's rights according to the principles of Islam, stating that, "women's private, social and domestic rights and the responsibilities must originate from and be consistent with Islamic laws" (Farzaneh 223). Under Article 20, men and women are deemed politically, economically, socially and culturally equal in accordance with Islamic rules (Roksana et al 2). Following the establishment of the Islamic Republic of Iran, women's rights were in accordance with the religious interpretation of Islam, creating many restrictions on women's rights because, "Islam certainly does not recognize identical rights, responsibilities, and punishments for women and men...Islam is not against equality between men and women; however, it is against similar rights" (Farzaneh 226).

Despite a constitutional guarantee of equality for women, the Islamic interpretation of 
what a women's role is and how women should service society limits these rights from being fully actualized. Built-in gender inequality and violence against those who resist oppressive laws coupled with increased discrimination against women is justified as being divinely derived from Islamic principle and facilitates the perpetuation male dominance in Iran:

Whether it is the language of game and the constant denial of discrimination against women carved in the Iranian legal system; using the physical and emotional differences between women and men (Islamic principal) as valid justification for treating women in front of the world; or using explicit declarations of a male gender requirement for decision-making judiciary positions such as judgeship results in Iranian women's social, political and legal rights being systematically violated and hey are treated as second-class citizens. (237)

In Iran today, little has changed for women as, "gender issues are hidden under the guise of Islamic ideology" (Mohammadi 2). The Iranian Constitution states that the family is the essential building block of society and that a woman's most important duty is serving in her role as a mother, as motherhood is undeniable right for women. The societal expectation that a woman is responsible for building strong Iranian family limits a woman's ability to participate in the world outside the home. Women cannot work, divorce, or travel without permission from a male. Women cannot obtain custody for their children and can be legally married at the age of 13. Women have no personal access to contraceptives to prevent pregnancies that may limit their opportunity to seek out employment and education. Women have no recourse for abuse or rape, endure gender segregation and state-sponsored, gender biased dress code. Women cannot partake in the armed forces or sing over radio or recording medium. Girls 9 or older can be held criminally responsible, while women are banned from decision making roles. Perhaps the most 
damaging idea for women in Iran is the idea that a woman with a public role is morally corrupt and lacking chastity (Mohammadi 3).

Considering the struggle of Iranian women to express themselves freely, make the their own decisions, get a job, receive uncensored education, hold a influential position, and simply attain the basic equality promised in their country's constitution, it is not hard see why gender relations in Iran are a controversial topic--because men and women in Iran do not enjoy the same human rights. Despite an equality guarantee for women, the Islamic interpretation of women's rights creates built-in gender inequality. Almost immediately after the Islamic state was established, the Family Protection Law was repealed because it was interpreted as infringing upon men's rights and thus against Islam. In the Islamic Republic of Iran today, little has changed for women as,"gender issues are hidden under the guise of Islamic ideology" (Mohammadi 2).

The present regime faces some of the same issues that those of the past has in terms of legitimacy. Because not all Iranians feel that their government is a representation of them, in recent years the state has had to field questions about how accurate the results of state held elections are. The establishment of an Islamic state in the aftermath of the 1979 Revolution was not the desired outcome for many Iranians who now must live in an Islamic state. Iran's persistence to remain a conservative Islamic state that has a reputation for shutting down opposition has caused damage to the relations between Iran and many world powers and institutions.

In order to analyze the Islamic Republic's essence and performance, it is important to assess the imprint of fundamentalist Shiism on structural and functional patterns of the 
government, the extent in which the 1979 Revolution has benefited the Iranian people, how successful the government has been in delivering on the promises of the revolution, state improvements, and setbacks the government has faced in the decades since the establishment of the Islamic state.

Khomeini published a series of works criticizing the Shah's government and defending a conservative, fundamentalist reading of Islam as well as the function of important Islamic figures like the Ulama. One concept that become inexplicably attached to Khomeini is Wilayat-e-faqih, which was based off Khomeini's belief in a, "complete subordination to the political institutions of Islam" and, "governance of the faqih as the real wielders of legislative, executive, and judicial power" in addition to the, “duties incumbent upon every Muslim in establishing an Islamic government" (Hashemi-Najafabadi 206).

Luckily for the fundamentalists, the Iranian people were becoming increasingly dissatisfied with the unregulated government under the Pahlavi Shahs. As the fundamentalist movement gained more support, the turn from traditionalist to full fundamentalist would occur with the sweep of the 1979 Revolution. It is true that "no one can deny the important impact that the revolution of 1979 and its aftermath had, and after the revolution, Khomeini became known as an Imam (Moazami 2). Khomeini's Imam status gave him ultimate religious and political authority and would alter the path of the Iranian people beyond what many had ever imagined.

After coming to power, Khomeini changed some elements of his most basic beliefs to accept the Iranian constitution, which he had previously stated was illegal in the eyes of Islam (Baktiari 40). He reasoned that this was necessary because a national constitution is a "modern institutions normally identified with democracy"(Hashemi-Najafabadi 204). He also started to 
support a "dual notion of sovereignty between clerical and lay people" baring that authority would rest with the latter (Hashemi-Najafabadi 206). Additionally, in 1988 Khomeini attempted to, "modernize Shiite jurisprudence by making it more practical"(Hashemi-Najafabadi 206). This met that he intended to mend facets of the Iranian legal and governmental systems which would allow for interference with the practice of Islamic law if expediency was required (Hashemi-Najafabadi 206). As the Islamic Republic of Iran became more comfortably established, it "modernized and bureaucratized the clerical establishment, redefined religion and created institutions to enforce this new definition" (Khaljaji 1).

Given this explanation of how religion has come to impact the modern shape of Iran following the 1979 Revolution when attempting to determine if the revolution benefited the Iranian people, the answer to that answer depends on what you wanted from the revolution. I an effort to amass a strong coalition to fight in the name of the revolution, Khamenei promised many different things to many different groups of Iranians with different interests. So unless you were a member of the religious elite suffering under the Shah or an Iranian citizen that believes in the ideals of establishing a fundamentalist Islamic state, then there are not many benefits that come out the revolution. For anyone that may have been interested in secular, Western ideas like culture or democracy, these interests were banished under the rule of the Islamic state.In exchange for women's contributions to the revolution effort, Khomeini promised women more access to basic rights, but under the establishment of the Islamic state, women only have simplistic and relatively unprotected rights as dictated by a narrow reading of Islam. It is not difficult to determine that the Islamic Republic of Iran has done an admirable job at establishing a fundamentalist Islamic state, however that is not what was promised to the vast majority of the 
Iranian people and thus they government that came to power and that has ruled since has not done enough to delivery of their pre-revolutionary promises.

Similarly, unless an Islamic state is what an individual desired as a result of the revolution, then there has not been any improvements to the lives of many Iranian citizens outside of the elite class since the inception of the Islamic Republic. After the death of Khomeini, a greater push for more consolidated power as justified by religion occurred, which resulted in a failed attempt to find a replacement for welayt-ye-faqih (Hashemi-Najafabadi 206). As discussed by Navid Fozi in his article "Governmentality and Crises of Representation, Knowledge, and Power in the Islamic Republic of Iran”, one of the most interesting issues concerning the legitimacy of the Iranian government occurred during the 2009 election, when many Iranians demanded a recount for fear of governmental interference. What followed was a distributing chapter in modern Iranian history that involved "state-sponsored vigilantism" and mistreatment of protesters. The uncertainty and turbulence that exist within the Iranian government have opened the door for some to question the government's legitimacy and structure, which is one of the greatest setbacks that the Iranian state faces today. This has lead to a culture is ruling by oppression and dependence rather than by legitimacy and desire (Azadarmaki 48).

Other then the fight for state legitimacy, some other setbacks that may impact Iran's ability to have crucial changes that would allow the nation to be more accepted in the eyes of “developed nations” are women's rights, human rights, democracy, separation of church and state, and more openness to engaging in the global secular economy. Despite these setbacks, Iran could still persist in its current state regardless of outside pressure of change unless the Iranian 
people demand change. The future success or failure of Iran is contingent upon the people's ability to resist oppressive tactics and the state's ability to adapt to what is best for their people over what best caters to tradition.

\section{Middle Ground Politics in Iran (2000-Present)}

In the book Understand Shiite Leadership: The Art of Middle Ground in Iran and Lebanon, authors Shaul Mishal and Ori Goldberg explore how the Shiite leadership of Iran interacts with the world "contrary to the violent and radical image of the religious leadership" and how the "political vision and practice of [Shiite] leaderships view the world as a "middle ground", shying away from absolutist and extremist tendencies" (Mishal et al 1). The authors also argue that the Islamic Republic of Iran is a "pragmatic, interpretative entity with the potential to form fruitful relationships between Shiite leadership and the non-Shiite world" (Mishal et al 1).

The introductory chapter of this book describes the questions that many global actors had after the establishment of the Islamic Republic of Iran. This section offers a discussion that compares various perspectives on "Shiite Religiously". Here the authors describe the point of view of Hamid Dabashi, Ervand Abrahamian, and Amir Arjomand. Dabashi views Shi'ism as an "cultural entity" that can shape "intangible aspects of being - morality, intellect, faith, reason, memory" (Mishal et al 2). Abrahamian attempts to deconstruct the commonly argument that the regime that Khomeini instituted in the aftermath of the 1979 Revolution was based off fundamentalist Islam, instead arguing that, "Khomeini did not offer blind adherence to a single sacred text, did not reject Western modernity, and did not accept other conversion of fundamentalism" (Mishal et al 3). Arjomand puts a historical emphasis on the understanding of 
how important Shi' ism is in Iran, stating that the primary function of religiosity "is a reflection of power struggles between economic classes" and that "religious practices and ideologies are a reflection of the material powers that drive and regulate social orders" (Mishal et al 5). These three authors are connected by their mutual belief in a "high-ground approach to religion" which involves a more nuanced understanding of "psychological processes, economic forces, and historical narratives"(Mishal et al 5). This contrasts with the authors argument that the Islamic state of Iran exists in a middle ground state, which still puts emphasis on the role of psychological, economic and historical factors and how they shape reality but "the boundaries of the middle ground are solidy defined by unimpeachable truths" (Mishal et al 6). The authors describe one of these "unimpeachable truths" is the "faith in God as sole sovereign, rather than the state or the people" (Mishal et al 6). The middle ground that the authors propose, that they argue Iran has been progressively inching towards, "resits the ultimate satisfactions of absolute truths just as it acknowledges and is inspired by such truths" (Mishal et al 6).

The authors argue that the middle ground developed from the "void, interpretation, and friction" (Mishal et al). The void refers to the state of Islamic thought in the absence of the Imam (Mishal et al 6). Interpretation refers to "the main practice of Shiite community" and friction refers to "the practical axis of the Shiite middle ground" (Mishal et al 7). These are concepts that are central to the arguments that Mishal and Goldberg will build upon later in the book.

For example, the authors argue that the design of the Iranian constitution is set up to to protect issues that fall within the middle ground. This works because the branches of government are arranged in a way that "ensures conflict between them" (Mishal et al 55). This friction serves as a distraction between different branches or groups while the elites come up with a way to 
cease the friction what still adheres to the values of the middle ground. But if this is not possible and because Allah is has exclusive "sovereignty and right to legislate", the government is designed to "introduce a third way, transforming exclusionary conflict into friction and a more desirable mode of action to challenge unsolvable issues(Mishal et al 56). The Iranian government views "conflict as an anomaly" and is expertly designed to operate within a friction based system, (Mishal et al 56).

The authors argue that since the years after the 1979 Revolution when the current Islamic state was established, the critical function of the state has been to "promote Islamic solidarity"(Mishal et al 57). The leaders of the new state attempted to implementation a strict Islamic based state but they also attempt to pacify revolutaries with adoption of some policies that were initially promised. This helped to contribute to the balance of friction in Iran. This has resulted in Shi'ism becoming more and more entrenched in the definition of Iranian tradition, which has been successfully perpetuated through "three distinct strategic behavioral modes traditional, conformist, and revolutionary" (Mishal et al 58). The traditional mode concerns commonly held traditional ideals and behaviors within society and is most commonly associated with the communal space, the conformist mode relates to institutional space and is focused on adhering to the dominant thoughts and actions at a particular time in society, and lastly revolutionary mode is connected to the frontier and it is concerned with a desire to go against the present state and conformist ideals (Mishal et al 58).

These three modes are kept in balance in order to maintain middle ground. Because this balance is what is most important, "middle ground politics of the Islamic Republic [are] not based on triumph or defeat" (Mishal et al 69). The government generally will have to mediate 
between parties in order to come up with a compromised third solution to problems so parties are generally aware that their goals will not be actualized exactly as they were imagined (Mishal et al 69). In summary:

An attempt on the part of one strategic mode to achieve dominance over the others is considered to be an anomaly. Effective leadership and middle ground reality gravitate toward a balance. (Mishal et al 70)

In the case of Iran, the authors contend that one of them most successful examples of Iranian middle ground politics took place during the 2013 elections. While many Iranians did not accept the legitimacy of the elections, many ended up voting for the candidate that advocated for change from the inside of the government, which in turn would inspire a "return to equilibrium" (Mishal et al 98). Mishal and Goldberg believe that Rouhani represents a "maturation of Shiite middle ground" (Mishal et al 98).

The authors conclude that outsiders often times tend to examine the political climate of Iran from only the extremes. However, as Mishal and Goldberg have demonstrated in this book, there is clearly a healthy middle ground political aspect in Iran which is equally important as the extremes. The authors understand the intentions of Shiite leadership in a different way than many scholars, seeing a genuine attempt to change the state of the nation but not simply through extremest means. Unbeknownst to many in the global community a balance between "divine truth and human contextually" has made "Shiite leadership an unexpected pioneer of the middle ground" (Mishal et al 134). 


\section{Concluding Remarks}

Iran is a misunderstood nation that is often viewed as unstable and ripe for radicalism, but it is important to understand what keynote factors have shaped modern Iran. At every point in the evolution of Iran as a nation, the political leaders of the state have grappled with the question of politics and instituted policy that would either confirm or resist the dominant religious sentiment of the country.

Due to the historical importance of Shiite Islamic traditions throughout the progression of Iranian history, in the 20th Century during the reign of Reza Shah when the state begun to shift away from traditionalist ideals, this is a key moment that would influence the desire for the formation of a religious state. Adversationist regimes established by the Pahlavi Shahs from 1925-1979 were detrimental to the lower class traditionalists that made up the majority of the Iranian population. Because Sharia Islam is historically so deeply ingrained in the political structure of Iran, when the state has experienced political regimes that purposefully averted Shiite principles, generally the discord between the people and the government has festered quickly. The Islamic Republic's stand for country's sovereignty and territorial integrity against the foreign domination have been admired by Iranian population and has made the revolution more popular among its followers. Post-revolutionary Iranian governments have also significantly contributed to country's further development including improvement in health, education, and urban and rural development.

Given Iran's modern geopolitical orientation, it is important to understand how this commonly misunderstood state came to be. A more in depth understanding and appropriation for Iran's government and function may go a long way towards advancing Iran's relationships with 
Western nations. While there is certainly a liberal, secularist movement in Iran today, the opening of the country may take time given its turbulent history with foreign power. Further study and proper education on the history of Iran's relations to the West could possibly serve to foster greater understanding and patience between Iran and other world actors and lessen Iran's perception as radicalist or threatening.

In order to advance our understanding of the modern shape of Iran and the importance of Shiite Islam, it may be helpful to pursue further research more keenly focused on the development of the "two cultures" in Iran that widened the gap between Secularists and Traditionalists in Iran which were formed a result of Reza Shah's modernization reforms. Alternately, more emphasis should be put on the influence of the Constitutional Revolution on Khomeini's motivate and direction in the establishment of the Islamic Republic which are still perluated today. 


\section{Works Cited}

ACLU. "Your Right to Religious Freedom". January 21, 2018.

BBC. "Iran Profile: Timeline”.Web. 2018.

Baktiari, Bahman. 'The Islamic Republic of Iran: Sharia Politics and the Transformation of Islamic Law,' The Review of Faith \& International Affairs

Black, Antony. "Religion and Politics in Western and Islamic Political Thought: A Clash of Epistemologies?" The Political Quarterly, Vol. 81, No. 1, Jan.-Mar. 2010.

Channel One News. Inside Iran, Youtube. January 28, 2017.

Farzaneh, D. “One Step Forward, Two Steps Back: A Brief History of Legal Discriminations Against Women in Iran and the Violations of International Human Rights", Annual Survey of International \& Comparative Law, Volume 20, Issue 1, Article 12, 2014.

Fonzi, Navid. "Governmentality and Crises of Representation, Knowledge, and Power in the Islamic Republic of Iran”.Asian Politics \& Policy_Volume 7, Issue 1-2015.

Hendawi, Hamza. "Shiite Leadership Clash in Iran, Iraq". Washington Post. 2004.

Kiddie, Nikki. "Modern Iran: Roots and Results of Revolution”. Yale University Press, 2003.

Khalaji, Mehdi. 'Iran's Regime of Religion,' Journal of International Affairs”. Vol. 65 Issue 1, p131-147. 17p.

Kheirabadi, Masoud. Iran, Second Edition. May 1, 2011.

Milani, Abbas. "Zoroaster and the Ayatollahs.” The National Interest, no. 111, 2011, pp. 64-72.

Moazami, Behrooz .'Rethinking the Role of Religion in Iran's History and Politics".1796-2009,' Comparative Studies of South Asia, Africa and the Middle East, Volume 31, Number 1, 2011.

Mohammad,Karamouzian, Hamid Sharifi, and Ali Akbar Haghdoost, "Iran's shift in family planning policies: concerns and challenges," Int J Health Policy Manag. 2014 Oct; 3(5): 231-233.

Mohammadi, Majid. "Iranian Women and the Civil Rights Movement in Iran: Feminism Interacted”.Journal of International Women's Studies, Volume 9, Issue 1, Sept 2007.

Parsa, Misagh. "Ideology and Political Action in the Iranian Revolution." Comparative Studies of South Asia, Africa and the Middle East, vol. 31, no. 1, 2011, pp. 53-68 
Wahdat-Hagh, Wahied. The Third Form of Totalitarianism: "The Islamic Republic of Iran". Iran Human Rights Review, European Foundation for Democracy. 2019. Accessed January 21, 2018. 